JEMAP: Jurnal Ekonomi, Manajemen, Akuntansi, dan Perpajakan

\title{
Peran Dimensi Motivasi Pelayanan Publik Dalam Meningkatkan Komitmen Afektif Pegawai
}

\author{
Iin Agustina ${ }^{1}$, Hafid Aditya Pradesa ${ }^{2}$, Ricky Adi Putranto ${ }^{3}$ \\ ${ }^{1}$ ien8307ez@gmail.com; ${ }^{2}$ hafid.pradesa@poltek.stialanbandung.ac.id; \\ ${ }^{3}$ ricky.putranto@poltek.stialanbandung.ac.id \\ ${ }^{1}$ Program Studi Administrasi Publik, Sekolah Tinggi Ilmu Administrasi Bandung \\ ${ }^{2}$ Politeknik STIA LAN Bandung
}

\begin{abstract}
Organizational commitment is considered as one of the most important results of public service motivation. There is also an important literature from management studies and organizational behavior that emphasizes affective commitment as the main component of organizational commitment. Based on that, the purpose of this study is to examine the role of the dimensions of public service motivation on employee affective commitment. By using a quantitative approach, the research model was built and tested on 179 research respondents, who were public officer work in the area of Bandung, West Java. Multiple regression analysis is used to analyze the data, with the criteria valid for validity and reliability test. The findings showed that of the four dimensions of public service motivation, it was found that only two significantly affected affective commitment, which were variable commitment to the public interest and variable compassion.
\end{abstract}

Keywords : Public Service Motivation; Dimensions of Public service motivation; Affective Commitment.

\section{PENDAHULUAN}

Organisasi sektor publik menghadapi tekanan luar biasa untuk menyesuaikan diri dengan tuntutan konstituen mereka yang baru dan terus berubah (Austen \& Zacny, 2015). Gagasan birokrasi dalam organisasi publik, dalam banyak hal, terkait erat dengan peran substansial yang dimainkan oleh kontrol eksternal dalam menciptakannya. Komitmen ditingkatkan ketika pegawai yang bekerja di sektor publik di lingkungan kolegial yang diindoktrinasi dengan nilainilai pelayanan publik. Dengan demikian, seseorang dapat mengandaikan bahwa efektivitas organisasi publik bergantung pada budaya pelayanan publik yang pada gilirannya dapat menciptakan kepuasan kerja dan komitmen profesional di antara para pegawainya.

Pegawai yang bekerja pada sektor publik dapat berargumentasi bahwa individu dengan sistem nilai yang berbeda atau kepribadian akan menunjukkan berbagai jenis komitmen. Namun sebagai konsep teoritis, komitmen organisasional 
JEMAP: Jurnal Ekonomi, Manajemen, Akuntansi, dan Perpajakan

ISSN: 2622-612X (Media Online) | Vol.4 | No.2 | Oktober 2021

telah melalui tradisi penelitian yang panjang dengan mencakup batasan disiplin ilmu dan wilayah yang sangat luas. Model komitmen organisasional yang didasarkan pada sektor publik harus menghindari efek pembingkaian dari setiap disiplin ilmu karena manajemen publik terletak di "persimpangan disiplin" ilmu politik dan perilaku organisasi (Pandey \& Wright, 2006). Perhatian baru-baru ini diberikan pada keterlibatan dan komitmen dalam literatur manajemen popular cenderung memusatkan perhatian pada kesejahteraan emosional saat mendeskripsikan komitmen pegawai untuk organisasinya (Mercurio, 2015). Oleh karena itu komitmen organisasional afektif dipertimbangkan sebagai hal terpenting yang dihasilkan dari mekanisme yang ada pada organisasi (Eby et al., 1999; Herscovitch \& Meyer, 2002) dan secara khusus pada organisasi publik (Pradesa, 2018; Pradesa et al., 2019).

Komitmen organisasional dan motivasi pelayanan publik mempunyai implikasi penting bagi pegawai sebagai individu dan organisasi yang mempekerjakan individu tersebut. Pertama, studi penelitian sebelumnya telah menunjukkan bahwa organisasi pelayanan publik lebih cenderung mempekerjakan individu yang cita-cita dan keinginannya sesuai dengan misi organisasi (Crewson, 1997; Perry \& Wise, 1990). Oleh karena itu, motivasi pelayanan publik atau public service motivation dipandang sebagai komponen dari kinerja individu yang mungkin penting. Kedua, penelitian oleh Meyer \& Allen, (1997) dan lainnya (misalnya (Porter et al., 1974; Stazyk et al., 2011) telah menyarankan bahwa organisasi menghargai komitmen organisasional karena berdampak positif pada prestasi kerja dan motivasi kerja dan mengurangi ketidakhadiran dan pergantian. Dengan demikian, komitmen organisasional tampaknya memiliki konsekuensi yang berpotensi serius bagi kinerja individu dan organisasi secara keseluruhan. Selain itu, pegawai yang berkomitmen mungkin lebih cenderung terlibat dalam perilaku peran ekstra, seperti kreativitas atau inovasi yang penting untuk mempertahankan sikap proaktif organisasi.

Berdasarkan latar belakang tersebut maka penelitian ini bertujuan untuk menguji dimensi dari konsep motivasi pelayanan publik dan sejauhmana pengaruhnya terhadap komitmen afektif pegawai yang bekerja di organisasi publik. 
JEMAP: Jurnal Ekonomi, Manajemen, Akuntansi, dan Perpajakan

ISSN: 2622-612X (Media Online) | Vol.4 | No.2 | Oktober 2021

Penelitian ini diharapkan untuk menjawab pertanyaan penelitian sebagai berikut :

"apa dimensi motivasi pelayanan publik yang paling mempengaruhi komitmen afektif yang dirasakan oleh pegawai ?".

\section{TINJAUAN PUSTAKA}

\section{Motivasi Pelayanan Publik}

Motivasi pelayanan publik didefinisikan sebagai "kecenderungan individu untuk menanggapi motif yang didasarkan terutama atau unik di lembaga dan organisasi publik" (Perry \& Wise, 1990). Teori PSM menyatakan bahwa individu dengan motivasi pelayanan publik yang lebih tinggi cenderung bekerja dan berkinerja lebih baik dalam organisasi publik. Teori tersebut berpendapat bahwa perilaku individu bukan hanya produk pilihan rasional dan pilihan pribadi, tetapi juga berakar pada motif normatif dan afektif (Christensen et al., 2017; Perry et al., 2006). Memahami motivasi dari perspektif rasional dan berbasis insentif hanya memberikan sedikit pemahaman tentang motivasi . Dipandang perlu mempelajari proses sosial yang membentuk keyakinan normatif dan pemahaman emosional individu terhadap dunia, termasuk tentang keyakinan dan pemahaman seorang pegawai negeri sipil dalam dunia pelayanan publik yang digelutinya (Kjeldsen \& Jacobsen, 2013).

Pegawai publik diharapkan bertindak untuk kepentingan masyarakat dan memajukan kepentingan umum (Amegavi \& Mensah, 2020). Hal ini memberikan tekanan yang sangat besar pada mereka dalam menjalankan peran pekerjaan mereka. Komitmen untuk kepentingan publik adalah cara yang jelas untuk mempromosikan kepentingan publik. Sejauh yang berhasil diidenfitikasi, dimensi komitmen untuk kepentingan publik merupakan hal terpenting dalam merefleksikan motivasi pelayanan publik yang dirasakan pegawai saat bekerja pada organisasi publik atau pemerintahan.

Apa yang memotivasi individu untuk melayani organisasi publik atau nirlaba? Rainey, (1982) mengacu pada motivasi untuk layanan publik sebagai "kecenderungan individu untuk menanggapi motif yang didasarkan secara unik di lembaga publik", telah menginspirasi kerangka kerja public service motivation atau 
JEMAP: Jurnal Ekonomi, Manajemen, Akuntansi, dan Perpajakan

ISSN: 2622-612X (Media Online) | Vol.4 | No.2 | Oktober 2021

motivasi pelayanan publik (Perry et al., 2010; Perry \& Wise, 1990) dan skala pengukuran yang terbentuk dan telah diuji (Perry, 1996) dan telah bertahan selama lebih dari dua dekade dengan banyak mengalami replikasi dan penyempurnaan (Harari et al., 2017).

\section{Komitmen Afektif}

Komitmen di tempat kerja adalah sebuah konsep yang telah menarik banyak perhatian dari para ahli di berbagai disiplin ilmu termasuk psikologi industri, sosiologi industri, manajemen, administrasi bisnis dan administrasi publik. Seberapa jauh komitmen pegawai terhadap organisasi sangatlah menentukan organisasi itu sendiri dalam mencapai tujuannya. Model yang disajikan oleh Meyer dan Allen (Herscovitch \& Meyer, 2002; Meyer \& Allen, 1997; N. Allen \& J. Meyer, 1990) berasumsi bahwa komitmen akan dapat mengikat individu secara psikis dan emosional pada suatu organisasi, dan hal tersebut bisa dicirikan oleh pola pikir yang berbeda. Secara umum pola pikir tersebut dapat dikategorikan menjadi tiga tema utama: "keterikatan afektif dengan organisasi (afektif), biaya yang dirasakan apabila meninggalkan organisasi (kontinuan), dan kewajiban untuk tetap bersama organisasi (normatif)" (Meyer \& Allen, 1997). Untuk selanutnya label yang secara umum diberikan adalah tentang tiga dimensi komitmen organisasional Meyer dan Allen. Sementara dari ketiga dimensi tersebut komitmen afektif tampaknya paling dapat diterapkan pada pegawai yang bekerja di organisasi publik. Komitmen afektif terkadang disebut sebagai komitmen sikap dan merupakan keterikatan emosional yang dimiliki seseorang untuk organisasi (Mercurio, 2015). Teorinya adalah bahwa seseorang akan berkontribusi ketika mereka memiliki sikap positif terhadap organisasi dan tujuan serta nilainya. Pegawai yang masuk atau tinggal di suatu organisasi harus memiliki komitmen afektif yang kuat terhadap organisasi, karena keinginan mereka untuk berkontribusi berasal dari proses yang cermat dalam "memilah-milah prioritas, dan mengelola kapabilitas dan kepentingan pribadi"

Penelitian telah menunjukkan bahwa, secara keseluruhan seseorang yang secara afektif berkomitmen pada sebuah organisasi akan memiliki kepuasan kerja yang lebih tinggi, akan lebih cenderung menunjukkan organisasi perilaku kewarganegaraan (Feather \& Rauter, 2004). Selain itu komitmen afektif merupakan 
JEMAP: Jurnal Ekonomi, Manajemen, Akuntansi, dan Perpajakan

ISSN: 2622-612X (Media Online) | Vol.4 | No.2 | Oktober 2021

hasil penting dari beberapa mekanisme yang ada pada organisasi seperti iklim etis (Pradesa, 2018; Pradesa et al., 2019) maupun kepuasan kerja dan motivasi (Culpepper, 2000; Herscovitch \& Meyer, 2002).

\section{Hubungan Diantara Motivasi Pelayanan Publik Dengan Komitmen Afektif}

Motivasi pelayanan publik seringkali diasosiasikan dengan komitmen organisasional sebagai bentuk hasil sikap individu (Austen \& Zacny, 2015; Potipiroon \& Ford, 2017; Supriatna et al., 2019). Pendekatan teoritis untuk penelitian penelitian ini didasarkan pada pemikiran bahwa pegawai negeri sipil yang bekerja di organisasi publik memiliki motif yang sesuai dengan konsep motivasi pelayanan publik.

Berangkat dari fenomena empiris mengenai pegawai negeri sipil termasuk didalamnya fenomena hasil penelitian terdahulu tentang beberapa hal yang dikaitkan dengan komitmen afektif pegawai. Meskipun ada beberapa penelitian yang menggunakan motivasi pelayanan publik sebagai variabel penjelas untuk sikap individu lainnya yang terbentuk, terdapat alasan meyakini bahwa kegunaan spesifik dari motivasi pelayanan publik adalah menjelaskan motivasi kerja dari individu yang bekerja pada konteks pemerintahan atau pelayanan publik (Boruvka \& Perry, 2020; Christensen et al., 2017). Komitmen afektif mewakili keterikatan emosional dari anggota organisasi (Mercurio, 2015), dan motivasi adalah korelasi positif yang diketahui dari komitmen organisasi afektif (Eby et al., 1999; Mathieu \& Zajac, 1990). Berdasarkan hal tersebut, komitmen afektif dapat dikorelasikan sebagai hasil dari motivasi pelayanan publik.

\section{Penelitian Terdahulu}

Persepektif teoritis telah memberikan pemahaman penting bahwa motivasi dan komitmen dapat berhubungan satu sama lain. Tabel 1 sebagai berikut merupakan hasil pemetaan literatur terdahulu yang mengulas diantara motivasi pelayanan publik dengan komitmen organisasional.

Tabel 1. Penelitian Terdahulu

\begin{tabular}{|c|l|l|l|}
\hline No. & $\begin{array}{l}\text { Judul, Nama Peneliti, dan } \\
\text { Tahun Literatur }\end{array}$ & Variabel Penelitian & \multicolumn{1}{|c|}{ Hasil Penelitian } \\
\hline 1. & $\begin{array}{l}\text { Analisis Motivasi Pelayanan } \\
\begin{array}{l}\text { Publik dan Role Stress } \\
\text { Terahdap Kinerja Pegawai }\end{array}\end{array}$ & $\begin{array}{l}\text { 1) Role Stress } \\
\text { 2) Motivasi } \\
\text { pelayanan publik }\end{array}$ & $\begin{array}{l}\text { Motivasi Pelayanan Publik } \\
\text { berpengaruh terhadap }\end{array}$ \\
\hline
\end{tabular}


JEMAP: Jurnal Ekonomi, Manajemen, Akuntansi, dan Perpajakan

\begin{tabular}{|c|c|c|c|}
\hline No. & $\begin{array}{c}\text { Judul, Nama Peneliti, dan } \\
\text { Tahun Literatur }\end{array}$ & Variabel Penelitian & Hasil Penelitian \\
\hline & $\begin{array}{l}\text { Dengan Komitmen Organisasi } \\
\text { Sebagai Variabel Intervening } \\
\text { Pada PT Kereta API Indonesia } \\
\text { DAOP VIII } \\
\text { (Widarni \& Irawan, 2020) }\end{array}$ & $\begin{array}{l}\text { 3) Komitmen } \\
\text { Organisasi } \\
\text { 4) Kinerja Pegawai }\end{array}$ & $\begin{array}{l}\text { Komitmen organisasi dan } \\
\text { terhadap kinerja pegawai }\end{array}$ \\
\hline 2. & $\begin{array}{l}\text { Improving Performance: } \\
\text { Motivation of Public Service } \\
\text { Officers and their } \\
\text { Commitment (Guswandi et } \\
\text { al., 2020) }\end{array}$ & $\begin{array}{l}\text { 1) Motivasi pelayanan } \\
\text { publik } \\
\text { 2) Komitmen } \\
\text { organisasional } \\
\text { 3) Kinerja pegawai }\end{array}$ & $\begin{array}{l}\text { Motivasi pelayanan publik } \\
\text { dan komitmen berpengaruh } \\
\text { terhadap kinerja pegawai } \\
\text { ditengah pembatasan sosial } \\
\text { skala besar }\end{array}$ \\
\hline 3. & $\begin{array}{l}\text { Commitment to public interest } \\
\text { and public service motivation } \\
\text { development challenges: A } \\
\text { qualitative inquiry } \\
\text { (Amegavi \& Mensah, 2020) }\end{array}$ & $\begin{array}{l}\text { Public Service } \\
\text { Motivation (Eksplorasi } \\
\text { komitmen pada } \\
\text { kepentingan publik) }\end{array}$ & $\begin{array}{l}\text { komitmen terhadap } \\
\text { kepentingan publik } \\
\text { dipengaruhi oleh tindakan } \\
\text { kepemimpinan dan budaya } \\
\text { organisasi. Hasil dari } \\
\text { makalah ini berguna bagi } \\
\text { organisasi publik dalam } \\
\text { upaya mereka untuk } \\
\text { memperbaiki diri } \\
\text { komitmen dan produktivitas } \\
\text { pegawai di sektor publik }\end{array}$ \\
\hline 4. & $\begin{array}{l}\text { Does Public Service } \\
\text { Motivation Matter to } \\
\text { Employees' Performance and } \\
\text { Organizational Commitment } \\
\text { in Sub-district Offices? } \\
\text { (Pratama \& Nurhidayah, } \\
\text { 2019) }\end{array}$ & 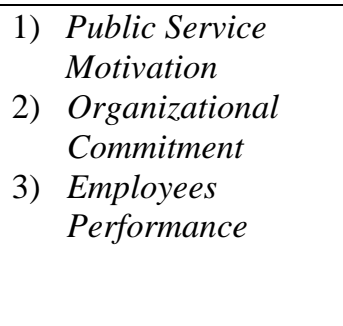 & $\begin{array}{l}\text { Hasil penelitian } \\
\text { memvalidasi temuan } \\
\text { penelitian sebelumnya yang } \\
\text { menunjukkan adanya } \\
\text { pengaruh positif motivasi } \\
\text { pelayanan publik terhadap } \\
\text { komitmen organisasi dan } \\
\text { kinerja individu. }\end{array}$ \\
\hline 5. & $\begin{array}{l}\text { The effect of public service } \\
\text { motivation on job } \\
\text { performance through } \\
\text { satisfaction and commitment: } \\
\text { case of public officer in } \\
\text { immigration office malang } \\
\text { (Hidayati \& Sunaryo, 2019) }\end{array}$ & $\begin{array}{l}\text { 1) Public Service } \\
\text { Motivation } \\
\text { 2) Job Satisfaction } \\
\text { 3) Organizational } \\
\text { Commitment } \\
\text { 4) Job Performance }\end{array}$ & $\begin{array}{l}\text { Motivasi pelayanan publik } \\
\text { berpengaruh positif terhadap } \\
\text { prestasi kerja pada pegawai } \\
\text { negeri di Kantor Imigrasi } \\
\text { Malang. Baik kepuasan dan } \\
\text { komitmen memperkuat efek } \\
\text { positif ini. }\end{array}$ \\
\hline 6. & $\begin{array}{l}\text { The Effect of Public Service } \\
\text { Motivation and Job } \\
\text { Satisfaction on Public } \\
\text { Officers' Performance } \\
\text { through Commitment } \\
\text { (Putranto et al., 2018) }\end{array}$ & $\begin{array}{l}\text { 1) Public Service } \\
\text { Motivation } \\
\text { 2) Job Satisfaction } \\
\text { 3) Organizational } \\
\text { Commitment } \\
\text { 4) Job Performance }\end{array}$ & $\begin{array}{l}\text { Motivasi pelayanan publik } \\
\text { tidak berpengaruh penting } \\
\text { pada komitmen } \\
\text { organisasional, tetapi } \\
\text { berpengaruh penting pada } \\
\text { kinerja pegawai. }\end{array}$ \\
\hline 7. & $\begin{array}{l}\text { Does Public Service } \\
\text { Motivation Always Lead to } \\
\text { Organizational Commitment? } \\
\text { Examining the Moderating } \\
\text { Roles of Intrinsic Motivation } \\
\text { and Ethical Leadership } \\
\text { (Potipiroon \& Ford, 2017) }\end{array}$ & $\begin{array}{l}\text { 1) Motivasi pelayanan } \\
\text { publik } \\
\text { 2) Kepemimpinan etis } \\
\text { 3) Komitmen } \\
\text { organisasional }\end{array}$ & $\begin{array}{l}\text { PSM berhubungan paling } \\
\text { positif dengan komitmen } \\
\text { organisasi bila disertai } \\
\text { dengan motivasi intrinsik } \\
\text { tinggi dan kepemimpinan } \\
\text { etis. }\end{array}$ \\
\hline 8. & $\begin{array}{l}\text { The role of Public Service } \\
\text { Motivation and }\end{array}$ & $\begin{array}{l}\text { 1) Motivasi pelayanan } \\
\text { publik }\end{array}$ & $\begin{array}{l}\text { Ada pengaruh timbal balik } \\
\text { antara PSM dan budaya }\end{array}$ \\
\hline
\end{tabular}


JEMAP: Jurnal Ekonomi, Manajemen, Akuntansi, dan Perpajakan

\begin{tabular}{|l|l|l|l|}
\hline No. & $\begin{array}{l}\text { Judul, Nama Peneliti, dan } \\
\text { Tahun Literatur }\end{array}$ & \multicolumn{1}{|c|}{ Variabel Penelitian } & \multicolumn{1}{c|}{ Hasil Penelitian } \\
\hline & $\begin{array}{l}\text { Organizational Culture for } \\
\text { Organizational Commitment } \\
\text { (Austen \& Zacny, 2015) }\end{array}$ & $\begin{array}{l}\text { 2) } \begin{array}{l}\text { Budaya } \\
\text { organisasional } \\
\text { Komitmen } \\
\text { organisasional }\end{array} \\
\text { 3) }\end{array}$ & $\begin{array}{l}\text { organisasi dan budaya } \\
\text { organisasi yang memoderasi } \\
\text { pengaruh motivasi } \\
\text { Pelayanan Publik terhadap } \\
\text { komitmen organisasional. }\end{array}$ \\
\hline
\end{tabular}

\section{Kerangka Konseptual Penelitian}

Berdasarkan teori dan hasil empiris yang telah disajikan pada bagian sebelumnya, diyakini bahwa motivasi pelayanan publik dapat menjadi anteseden dari komitmen afektif dari pegawai. Dalam penelitian ini kerangka konseptual yang diusulkan dapat menunjukkan hubungan antara empat dimensi dari motivasi pelayanan publik : ketertarikan pada pembuatan kebijakan publik, komitmen untuk kepentingan umum, kasih saying (compassion), serta pengorbanan diri (selfsacrifice) dan komitmen afektif. Oleh karena itu kerangka konseptual yang dikembangkan pada penelitian ini ditunjukkan oleh Gambar 1 sebagai berikut.

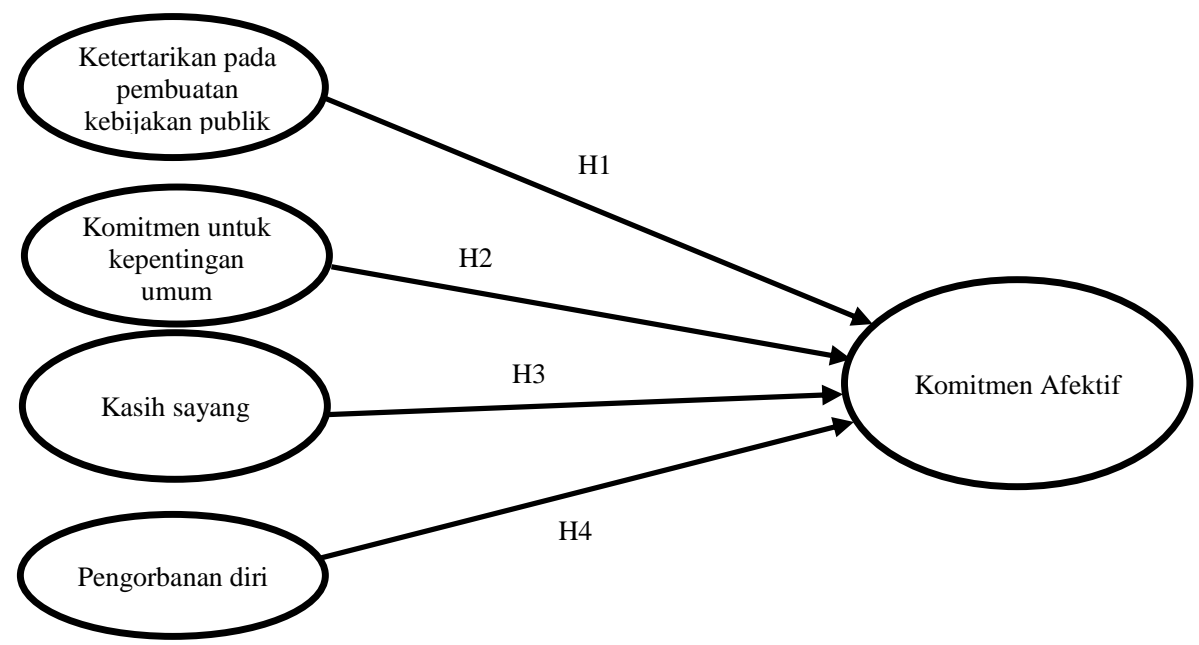

Gambar 1. Kerangka Konseptual Penelitian

\section{Hipotesis}

Untuk menyelidiki hubungan langsung antara variabel yang dibahas dalam penelitian ini, hipotesis penelitian tertentu harus diajukan dan kemudian diuji. Oleh karena itu, hipotesis dalam penelitian ini dinyatakan antara lain sebagai berikut:

H1. Ketertarikan pada pembuatan kebijakan publik mempunyai memiliki pengaruh positif dan signifikan terhadap komitmen afektif pegawai. 
H2. Komitmen untuk kepentingan umum mempunyai memiliki pengaruh positif dan signifikan terhadap komitmen afektif pegawai.

H3. Kasih sayang mempunyai memiliki pengaruh positif dan signifikan terhadap komitmen afektif pegawai.

H4. Pengorbanan diri untuk kepentingan umum mempunyai memiliki pengaruh positif dan signifikan terhadap komitmen afektif pegawai.

\section{METODE PENELITIAN}

Setelah meninjau tiga pertanyaan penelitian, beberapa topik desain penelitian utama mengikuti. Desain non-eksperimental dan metode kuantitatif diterapkan dalam penelitian ini. Data kuantitatif dikumpulkan, dan 4 hipotesis yang akan diuji, sehingga metode kuantitatif adalah pendekatan yang paling tepat dan praktis untuk penelitian ini. Penelitian kuantitatif ini didasarkan pada paradigma positivis, postpositivist, dan pragmatis mengenai sifat realitas sebagai objektif, pasti, dan dengan demikian dapat diukur.

Responden dalam penelitian ini adalah pegawai yang bekerja pada organisasi publik di Bandung dan sekitarnya. Pengumpulan data dilakukan dengan menggunakan instrument kuesioner yang disusun dalam bentuk google form untuk kemudian disebarkan kepada responden. Tehnik pengambilan sampel adalah nonprobability sampling dengan snowball sampling atau sampel bola salju.

Penelitian dimulai dengan populasi kecil individu yang dikenali pada grup media sosial dan memperluas sampel dengan meminta peserta awal tersebut untuk mengidentifikasi orang lain yang masuk kriteria dan berkenan untuk berpartisipasi dalam studi. Penelitian ini dilakukan pada bulan September 2020 dengan durasi waktu pengambilan data selama 40 hari. Setelah batas pengumpulan data terlewati, tercatat 187 responden yang berpartisipasi dalam penelitian dengan mengisi kuesioner. Tetapi dalam proses pengumpulan dan pemilahan data, sebanyak 8 kuesioner online yang diidenfikasi tidak lengkap dan tidak dimasukkan dalam proses pengolahan data lebih lanjut.

Data yang telah terkumpul dan selesai dipilah kemudian diolah menggunakan software SPSS, dengan memakai tehnik analisis regresi berganda. Tehnik analisis 
JEMAP: Jurnal Ekonomi, Manajemen, Akuntansi, dan Perpajakan

ISSN: 2622-612X (Media Online) | Vol.4 | No.2 | Oktober 2021

ini mempertimbangkan model penelitian kasualitas yang terdiri dari empat variabel independent dan satu variabel dependen. Selain itu basis dari pertanyaan penelitian yang menjadi pertimbangan lain mengapa tehnik analisis data ini digunakan. Sebelum data dianalisis, pengujian validitas dan reliabilitas dilakukan untuk memenuhi kriteria kelayakan instrumen pengumpulan data untuk kemudian dilaksanakan proses analisis data lebih lanjut.

\section{HASIL DAN PEMBAHASAN}

Statistik deskriptif dilakukan untuk melaporkan skor rata-rata, serta uji validitas dan reliabilitas untuk masing-masing konstruk yakni ketertarikan pada pembuatan kebijakan publik, komitmen untuk kepentingan umum, kasih sayang, pengorbanan diri dan komitmen afektif. Tabel 2 menunjukkan hasil analisis data untuk deskripsi jawaban responden berupa rerata nilai serta hasil koefisien korelasi untuk setiap indikator dalam variabel yang diamati pada penelitian ini. Nilai ratarata tertinggi adalah variabel kasih sayang (mean $=4,292$ ) sebagai bagian dari motivasi pelayanan publik, sementara nilai rata-rata terendah adalah variabel ketertarikan pada pembuatan kebijakan publik (mean $=4,00)$.

Tabel 2. Nilai Mean dan Koefisien Korelasi

\begin{tabular}{|l|c|c|}
\hline & $\begin{array}{c}\text { Mean } \\
\text { Rerata } \\
\text { Nilai) }\end{array}$ & $\begin{array}{c}\text { Koefisien } \\
\text { Korelasi }\end{array}$ \\
\hline Ketertarikan pada pembuatan kebijakan publik $(\boldsymbol{\alpha}=\mathbf{. 6 8 3})$ & $\mathbf{4 , 0 0}$ & \\
\hline $\begin{array}{l}\text { Menjadi pejabat dalam organisasi publik bisa mengubah ide bagus } \\
\text { menjadi undang-undang }\end{array}$ & 3,77 & .510 \\
\hline Perilaku etis pejabat publik sama penting dengan kompetensi & 4,27 & .462 \\
\hline Merasa pemberian dan pengambilan kebijakan publik menarik & 3,96 & .531 \\
\hline \multicolumn{1}{|c|}{ Komitmen untuk kepentingan umum $(\boldsymbol{\alpha}=\mathbf{. 7 3 6})$} & $\mathbf{4 , 2 0 7}$ & \\
\hline Tidak egois dalam berkontribusi pada komunitas & 4,17 & .589 \\
\hline Pelayanan publik yang berarti sangat penting & 4,35 & .570 \\
\hline $\begin{array}{l}\text { Kewajiban resmi kepada publik harus selalu didahulukan sebelum } \\
\text { loyalitas seorang pegawai kepada atasan }\end{array}$ & 4,09 & .532 \\
\hline $\begin{array}{l}\text { Patriotisme yang meliputi tentang bagaimana mengupayakan } \\
\text { kesejahteraan bagi orang lain }\end{array}$ & $\mathbf{4 , 2 9 2}$ & \\
\hline $\begin{array}{l}\text { Diingatkan oleh kejadian sehari-hari tentang betapa berharganya kita } \\
\text { satu sama lain }\end{array}$ & 4,23 & .583 \\
\hline Sering tergerak oleh penderitaan orang-orang yang kurang mampu & 4,33 & .538 \\
\hline \multicolumn{1}{|c|}{ Pengorbanan diri $(\boldsymbol{\alpha}=. \mathbf{7 8 9})$} & $\mathbf{4 , 1 1 0}$ & .611 \\
\hline $\begin{array}{l}\text { Menggunakan setiap energi untuk membuat dunia menjadi tempat } \\
\text { yang lebih adil }\end{array}$ & 4,23 & .709 \\
\hline
\end{tabular}


JEMAP: Jurnal Ekonomi, Manajemen, Akuntansi, dan Perpajakan

ISSN: 2622-612X (Media Online) | Vol.4 | No.2 | Oktober 2021

\begin{tabular}{|l|c|c|}
\hline Ada banyak penyebab umum yang patut diperjuangkan & 4,13 & .633 \\
\hline Memperjuangkan hak orang lain meskipun itu berarti akan diejek & 3,97 & .557 \\
\hline Komitmen Afektif $(\boldsymbol{\alpha}=\mathbf{8 7 9})$ & $\mathbf{4 , 0 4 0}$ & \\
\hline Merasa bangga bekerja di institusi & 4,35 & .719 \\
\hline Memiliki keterikatan emosional dengan tempat bekerja & 3,91 & .680 \\
\hline Merasa kesamaan nilai - nilai yang diyakini & 3,78 & .699 \\
\hline Mempunyai perasaan memiliki yang kuat & 4,14 & .758 \\
\hline Peduli terhadap kelanjutan nasib organisasi & 4,27 & .661 \\
\hline Merasa masalah organisasi adalah masalah pribadi juga & 3,79 & .629 \\
\hline
\end{tabular}

Koefisien korelasi signifikan pada level $p<.001$

Penelitian ini menggunakan analisis korelasi untuk menguji signifikansi dari nilai koefisien indikator pada variabel yang diamati dalam penelitian, sebagai kriteria untuk memeriksa validitas internal dari data penelitian yang terkumpul. Dengan cut-off sebesar 0,300 maka seluruh indikator sebagaimana ditunjukkan pada Tabel 2 telah memenuhi kriteria validitas, dengan range nilai koefisien korelasi dari 0,462 sampai dengan 0,758. Sementara nilai alpha Cronbach sebagai nilai reliabilitas ditemukan diantara 0,683 sampai dengan 0,879 yang berarti bahwa seluruh instrumen dalam penelitian ini dinyatakan memenuhi kriteria keandalan. Pada Tabel 2 memperlihatkan semua nilai $(\alpha)$ alpha $>0.6$, sehingga seluruh variabel yang diamati dalam penelitian ini dinyatakan reliabel.

Deskripsi jawaban dari responden menunjukkan bahwa mayoritas menilai bahwa kasih sayang (compassion) merupakan dimensi dari motivasi pelayanan publik penting dan paling cenderung ditunjukkan oleh pegawai sebagai motif utama dalam melayani publik. Menurut mayoritas responden dalam penelitian ini, pegawai yang bekerja di organisasi publik cenderung lebih mempunyai nilai diri yang berbeda terutama aspek kepekaan dan kepedulian sosial terhadap sesama sesama manusia sebagai makhluk hidup yang setara. Sementara meski masih dapat dikategorikan baik, ketertarikan pada pembuatan kebijakan publik mempunyai nilai terendah jika dibandingkan dengan nilai dari dimensi motivasi pelayanan publik lainnya.

Tabel 3. Nilai Koefisien Beta Untuk Hubungan Antar Variabel

\begin{tabular}{|l|c|c|c|c|}
\hline \multicolumn{1}{|c|}{ Pengaruh } & $\begin{array}{c}\text { Koefisien } \\
\text { Beta }\end{array}$ & $\begin{array}{c}\text { Nilai } \\
\text { tstatistik }\end{array}$ & Sign. & Ket \\
\hline $\begin{array}{l}\text { Ketertarikan pada pembuatan } \\
\text { kebijakan publik } \rightarrow \text { Komitmen Afektif }\end{array}$ & -.028 & -.326 & .745 & $\begin{array}{c}\text { Tidak } \\
\text { Signifikan }\end{array}$ \\
\hline $\begin{array}{l}\text { Komitmen untuk kepentingan umum } \\
\rightarrow \text { Komitmen Afektif }\end{array}$ & .258 & 2.373 & .019 & Signifikan \\
\hline Kasih sayang $\rightarrow$ Komitmen Afektif & .285 & 2.829 & .005 & Signifikan \\
\hline
\end{tabular}


JEMAP: Jurnal Ekonomi, Manajemen, Akuntansi, dan Perpajakan

ISSN: 2622-612X (Media Online) | Vol.4 | No.2 | Oktober 2021

\begin{tabular}{|l|c|c|c|c|}
\hline \multicolumn{1}{|c|}{ Pengaruh } & $\begin{array}{c}\text { Koefisien } \\
\text { Beta }\end{array}$ & $\begin{array}{c}\text { Nilai } \\
\mathbf{t}_{\text {statistik }}\end{array}$ & Sign. & Ket \\
\hline $\begin{array}{l}\text { Pengorbanan diri } \rightarrow \text { Komitmen } \\
\text { Afektif }\end{array}$ & .144 & 1.291 & .198 & $\begin{array}{c}\text { Tidak } \\
\text { Signifikan }\end{array}$ \\
\hline
\end{tabular}

Sumber: data primer yang diolah dengan SPSS (2020).

Gambar 2 menampilkan hasil analisis model, dengan estimasi parameter standar untuk model disajikan. Hasil penelitian menunjukkan bahwa ketertarikan pada pembuatan kebijakan publik $\left(\beta_{1}=-0,028, \mathrm{p}>0,05\right)$ tidak signifikan dalam mempengaruhi komitmen afektif. Oleh karena itu, hipotesis 1 ditolak. Komitmen untuk kepentingan umum $\left(\beta_{2}=0,258, \mathrm{p}<0,05\right)$, secara signifikan mempengaruhi komitmen afektif, sedangkan kasih sayang $\left(\beta_{3}=0,285, \mathrm{p}<0,05\right)$ secara signifikan mempengaruhi komitmen afektif. Hipotesis 4 dan hipotesis 3 diterima. Hasil penelitian menunjukkan bahwa pengorbanan diri $\left(\beta_{4}=0,144, \mathrm{p}>0,05\right)$ tidak signifikan dalam mempengaruhi komitmen afektif. Oleh karena itu hipotesis 4 ditolak atau tidak dapat dikonfirmasi dalam penelitian ini.

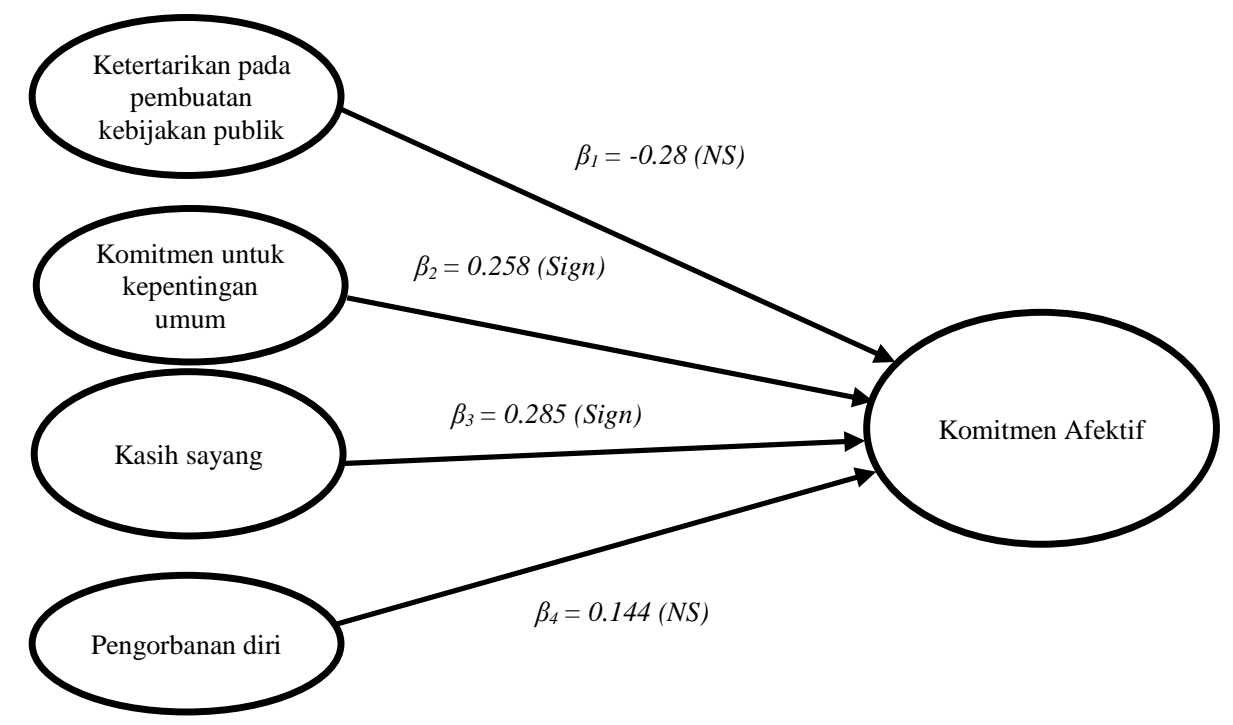

Gambar 2. Diagram Hasil Penelitian

Hasil penelitian ini tidak sejalan dengan penelitian sebelumnya yang dilakukan seperti (Jin et al., 2018; Potipiroon \& Ford, 2017) yang menegaskan bahwa motivasi pelayanan publik selalu mendorong komitmen organisasional dari individu yang bekerja pada organisasi publik. Hasil penelitian mengungkap temuan bahwa jika dilihat dari masing - masing dimensinya, maka motivasi pelayanan publik dapat memberikan hasil pengaruh yang berbeda. Hal yang menarik dari 
JEMAP: Jurnal Ekonomi, Manajemen, Akuntansi, dan Perpajakan

ISSN: 2622-612X (Media Online) | Vol.4 | No.2 | Oktober 2021

temuan ini adalah tentang menjelaskan pengaruh ketertarikan pada pembuatan kebijakan publik dan pengorbanan diri terhadap komitmen afektif. Keduanya tidak dapat berkontribusi penting dalam meningkatkan komitmen afektif dari seorang pegawai. Kedua dimensi ini dimungkinkan lebih dapat memprediksi sikap atau perilaku individu terkait pekerjaan, bukan terkait organisasi.

Dari nilai pengaruhnya, terlihat bahwa koefisien beta yang signifikan masih dalam taraf rendah - moderat $\left(\beta_{2}=0,258\right.$; dan $\left.\beta_{3}=0,285\right)$. Nilai koefisien terbesar ditunjukkan oleh pengaruh dimensi kasih sayang terhadap komitmen afektif. Ini menjadi salah satu temuan penting dalam penelitian ini sekaligus menjawab pertanyaan penelitian. Kasih sayang menjadi hal terpenting dari motivasi pelayanan publik seorang pegawai, dan seorang pegawai organisasi publik yang memiliki motif kepedulian terhadap sesama, rasa sosial yang tinggi, maka akan cenderung meningkatkan rasa keterikatan emosionalnya dengan organisasi.

\section{Tabel 4. Nilai Koefisien Determinasi dan Signifikansi Dari Model}

\begin{tabular}{|c|c|c|c|c|}
\hline Model & R & R Square & F & Sig. \\
\hline 1 & $.614^{\mathrm{a}}$ & .377 & 26.318 & $.000^{\mathrm{b}}$ \\
\hline
\end{tabular}

Sumber : data diolah dengan SPSS (2020)

Berdasarkan tabel 4 dapat diketahui bahwa nilai Rsquare dalam model penelitian ini ditemukan sebesar 0.377 menunjukkan varian dari model yang moderat. Dengan kata lain ketertarikan pada pembuatan kebijakan publik, komitmen untuk kepentingan umum, kasih sayang dan pengorbanan diri merupakan penjelas atau determinan dari komitmen afektif pegawai sebesar 37,70 persen. Sedangkan sisanya sebesar 62,30 persen merupakan faktor - faktor lain diluar keempat dimensi dari motivasi pelayanan publik tersebut. Sementara nilai F adalah 26.318 dengan signifikansi .000, yang berarti bahwa model ini secara keseluruhan dikategorikan sebagai baik. Model penelitian dapat dipertimbangkan sebagai model prediktif dalam menentukan komitmen afektif yang dirasakan pegawai sebagai dampak dari ketertarikan pada pembuatan kebijakan publik, komitmen untuk kepentingan umum, kasih sayang dan pengorbanan diri. Keempatnya yang merupakan dimensi dari motivasi pelayanan publik dapat dipertimbangkan sebagai determinan komitmen afektif. 
JEMAP: Jurnal Ekonomi, Manajemen, Akuntansi, dan Perpajakan

ISSN: 2622-612X (Media Online) | Vol.4 | No.2 | Oktober 2021

Bias telah diidentifikasi sebagai lebih rentan dalam tingkat respons yang rendah Ketika analisis difokuskan pada variabel individu tetapi ketika ini diperluas ke hubungan, efek bias cenderung tidak terjadi. Karena tujuan dari penelitian ini adalah untuk mengeksplorasi pengaruh diantara variabel yang berbeda, analisis dalam penelitian ini masih bermakna dengan potensi untuk memberikan pola yang ada dalam sampel penelitian.

\section{PENUTUP}

Tujuan dari penelitian ini adalah untuk memperluas literatur yang ada dengan menyelidiki hubungan antara motivasi dan komitmen dalam organisasi sektor publik. Secara khusus, penelitian ini dirancang untuk mengkaji peran daya tarik terhadap pembuatan kebijakan publik, komitmen terhadap kepentingan publik, kasih sayang, pengorbanan diri terhadap komitmen afektif sebagai hasilnya.

Temuan penelitian menunjukkan bahwa dua dari empat hipotesis penelitian ini yang diterima (pengaruh komitmen untuk kepentingan umum dan kasih sayang terhadap komitmen afektif), dan dua sisanya (pengaruh ketertarikan pada pembuatan kebijakan publik dan pengorbanan diri terhadap komitmen afektif) tidak dapat dikonfirmasi. Dimensi kasih sayang sebagai bagian dari motivasi pelayanan publik yang paling berpengaruh besar pada peningkatan komitmen afektif dari pegawai. Meski begitu, asumsi dasar penelitian ini sejalan dengan teori motivasi pelayanan publik yang mengasumsikan bahwa pegawai negeri memiliki motivasi pelayanan publik yang lebih tinggi jika dibandingkan dengan pegawai yang bekerja di sektor lain.

Studi ini menemukan bukti pegawai negeri sipil memiliki nilai-nilai motivasi untuk menjadi pegawai yang berkualitas dalam memberikan pelayanan publik sehingga kontribusinya akan positif bagi organisasi. Selain itu, dukungan ditemukan untuk mediasi parsial pengaruh motif ini pada komitmen organisasi afektif oleh organisasi orang. Akhirnya, hasil penelitian ini menunjukkan bahwa konsep motivasi pelayanan publik yang sebelumnya bersifat multidimensional masing - masing dimensinya dapat diuji secara terpisah dan digunakan mengukur 
JEMAP: Jurnal Ekonomi, Manajemen, Akuntansi, dan Perpajakan

ISSN: 2622-612X (Media Online) | Vol.4 | No.2 | Oktober 2021

motivasi pelayanan publik dari pegawai, terutama dalam konteks sektor publik. Terbukti bahwa hasil penelitian ternyata menunjukkan pola pengaruh yang berbeda diantara masing - masing dimensi tersebut.

Penelitian ini tidak terlepas dari beberapa keterbatasan mungkin dapat berakibat pada beberapa kekurangan yang muncul dalam penelitian. Keterbatasan yang diidentifikasi dalam penelitian ini antara lain bahwa penelitian ini tidak membedakan sampel berdasarkan karakteristik pribadi, termasuk mengkaji keterkaitan dengan persepsi pribadi yang dirasakan atas hal-hal lain selain yang tertera dalam model. Dikarenakan penelitian ini lebih memfokuskan pada menguji hubungan kausalitas antara variabel independen terhadap variabel dependen yang instrumen pengukurannya dikembangkan dari kajian teoritis maupun empiris terdahulu. Selain itu penelitian ini hanya dilakukan pada satu waktu (crosssectional study), artinya penelitian tidak bersifat longitudinal, tidak mempertimbangkan durasi waktu yang berbeda.

Memperluas penelitian motivasi pelayanan publik dan komitmen afektif saat ini ke bidang publik teori uji keamanan di mana sedikit bukti dari penyelidikan tersebut ada. Memperluas ini temuan dalam penelitian masa depan dapat terjadi dengan melibatkan berbagai lembaga. Pendekatan ini akan mengungkapkan apakah lembaga yang berbeda dalam bidang pekerjaan yang sama menghasilkan hasil yang serupa.

\section{DAFTAR PUSTAKA}

Amegavi, G. B., \& Mensah, J. K. (2020). Commitment to public interest and public service motivation development challenges: A qualitative inquiry. Public Administration Issues, 6(II), 67-83. https://doi.org/10.17323/1999-5431-2020-0-6-67-83

Austen, A., \& Zacny, B. (2015). The role of public service motivation and organizational culture for organizational commitment. Management, 19(2), 1-14. https://doi.org/10.1515/manment-2015-0012

Boruvka, E., \& Perry, J. L. (2020). Understanding evolving public motivational practices: An institutional analysis. Governance, 33(3), 565-584. https://doi.org/10.1111/gove.12460 
JEMAP: Jurnal Ekonomi, Manajemen, Akuntansi, dan Perpajakan

ISSN: 2622-612X (Media Online) | Vol.4 | No.2 | Oktober 2021

Christensen, R. K., Paarlberg, L., \& Perry, J. L. (2017). Public service motivation research: Lessons for practice. Public Administration Review, 77(4), 529542. https://doi.org/10.1111/puar.12796

Crewson, P. E. (1997). Public-service motivation: Building empirical evidence of incidence and effect. Journal of Public Administration Research and Theory, 7(4), 499-518. https://doi.org/10.1093/oxfordjournals.jpart.a024363

Culpepper, R. A. (2000). A test of revised scales for the Meyer and Allen (1991) three-component commitment construct. Educational and Psychological Measurement, $60(4)$, https://doi.org/10.1177/00131640021970754

Eby, L. T., Freeman, D. M., Rush, M. C., \& Lance, C. E. (1999). Motivational bases of affective organizational commitment: A partial test of an integrative theoretical model. Journal of Occupational and Organizational Psychology, 72(4), 463-483. https://doi.org/10.1348/096317999166798

Feather, N. T., \& Rauter, K. A. (2004). Organizational citizenship behaviours in relation to job status, job insecurity, organizational commitment and identification, job satisfaction and work values. Journal of Occupational and Organizational Psychology, 77(1), 81-94. https://doi.org/10.1348/096317904322915928

Guswandi, G., Nursyamsi, I., Sumardi, S., \& Hardiyono, H. (2020). Improving performance: Motivation of public service officers and their commitment. Hasanuddin Journal of Business Strategy, 2(2), 51-56. https://doi.org/10.26487/hjbs.v2i2.332

Harari, M. B., Herst, D. E. L., Parola, H. R., \& Carmona, B. P. (2017). Organizational correlates of public service motivation: A meta-analysis of two decades of empirical research. Journal of Public Administration Research and Theory, 27(1), 68-84. https://doi.org/10.1093/jopart/muw056

Herscovitch, L., \& Meyer, J. P. (2002). Commitment to organizational change: Extension of a three-component model. Journal of Applied Psychology, 87(3), 474-487. https://doi.org/10.1037/0021-9010.87.3.474

Hidayati, N., \& Sunaryo, H. (2019). The effect of public service motivation on job performance through satisfaction and commitment: case of public officer in immigration office malang. Journal of Entrepreneurship, Business and Economics, 7(1), 1-16. 
JEMAP: Jurnal Ekonomi, Manajemen, Akuntansi, dan Perpajakan

Jin, M. H., McDonald, B., \& Park, J. (2018). Does public service motivation matter in public higher education? Testing the theories of person-organization fit and organizational commitment through a serial multiple mediation model. American Review of Public Administration, 48(1), 82-97. https://doi.org/10.1177/0275074016652243

Kjeldsen, A., \& Jacobsen, C. (2013). Public service motivation and employment sector: Attraction or socialization? Journal of Public Administration Research and Theory, 23, 899-926.

Mathieu, J. E., \& Zajac, D. M. (1990). A Review and meta-analysis of the antecedents, correlates, and consequences of organizational commitment. Psychological Bulletin, 108(2), 171-194. https://doi.org/10.1037/0033$\underline{2909.108 .2 .171}$

Mercurio, Z. A. (2015). Affective commitment as a core essence of organizational commitment: An integrative literature review. Human Resource Development Review, 14(4), 389-414. https://doi.org/10.1177/1534484315603612

Meyer, J. P., \& Allen, N. J. (1997). Commitment in the workplace: Theory, research, and application. SAGE.

N. Allen, \& J. Meyer. (1990). The measurement and antecedents of affective, continuance and normative commitment to the organization. Journal of Occupational Psychology, 63, 1-18.

Pandey, S. K., \& Wright, B. E. (2006). Connecting the dots in public management: Political environment, organizational goal ambiguity, and the public manager's role ambiguity. Journal of Public Administration Research and Theory, 16(4), 511-532. https://doi.org/10.1093/jopart/muj006

Perry, J. L. (1996). Measuring public service motivation: An assessment of construct reliability and validity. Journal of Public Administration Research and Theory, 6(1), 5-22. https://doi.org/10.1093/oxfordjournals.jpart.a024303

Perry, J. L., Hondeghem, A., \& Wise, L. R. (2010). Revisiting the motivational bases of public service: Twenty years of research and an agenda for the future symposium. Public Administration Review, 70(5), 681-690. https://doi.org/10.3892/ijmm.8.5.549

Perry, J. L., Mesch, D., \& Paarlberg, L. (2006). Motivating employees in a new era: The performance paradigm revisited. Public Administration Review, 66(4), 505-514. 
JEMAP: Jurnal Ekonomi, Manajemen, Akuntansi, dan Perpajakan

Perry, J. L., \& Wise, L. R. (1990). The motivational bases of public service. Public Administration Review, 50(3), 367-373. https://doi.org/10.1111/j.1540$\underline{6210.2005 .00466 . x}$

Porter, L. W., Steers, R. M., Mowday, R. T., \& Boulian, P. V. (1974). Organizational commitment, job satisfaction, and turnover among psychiatric technicians. Journal of Applied Psychology, 59(5), 603-609. https://doi.org/10.1037/h0037335

Potipiroon, W., \& Ford, M. T. (2017). Does public service motivation always lead to organizational commitment? Examining the moderating roles of intrinsic motivation and ethical leadership. Public Personnel Management, 46(3), 1-28. https://doi.org/10.1177/0091026017717241

Pradesa, H. A. (2018). Peran komitmen afektif dalam memperkuat dampak dari dimensi iklim kerja etis terhadap perasaaan berkewajiban pegawai negeri sipil di kantor pemerintahan provinsi jawa barat. Jurnal Ilmiah Bisnis dan Ekonomi Asia, 12(2), 16-29.

Pradesa, H. A., Dawud, J., \& Affandi, M. N. (2019). Mediating role of affective commitment in the effect of ethical work climate on felt obligation among public officers. JEMA: Jurnal Ilmiah Bidang Akuntansi dan Manajemen, 16(2), 133-146. https://doi.org/10.31106/jema.v16i2.2707

Pratama, A. B., \& Nurhidayah, A. (2019). Does public service motivation matter to employees' performance and organizational commitment in sub-district offices? JKAP: Jurnal Kebijakan Dan Administrasi Publik, 23(1), 1-15. https://doi.org/10.22146/jkap.37913

Putranto, R. A., Setiajatnika, E., \& Fahmi, I. (2018). The effect of public service motivation and job satisfaction on public officers' performance through commitment. International Journal of Academic Research in Business and Social Sciences, 8(12), 1422-1435. https://doi.org/10.6007/ijarbss/v8-i12/5247

Rainey, H. G. (1982). Reward preferences among public and private managers: In search of the service ethic. The American Review of Public Administration, 16(4), 288-302.

Stazyk, E. C., Pandey, S. K., \& Wright, B. E. (2011). Understanding affective organizational commitment: The importance of institutional context. American Review of Public Administration, 41(6), 603-624. https://doi.org/10.1177/0275074011398119

Supriatna, M. D., Pradesa, H. A., \& Priatna, R. (2019). Literature review and conceptual models development on public services motivation. 
JEMAP: Jurnal Ekonomi, Manajemen, Akuntansi, dan Perpajakan

ISSN: 2622-612X (Media Online) | Vol.4 | No.2 | Oktober 2021

Warmadewa Management and Business Journal (WMBJ) Agustus, 1(2), 102-110. https://ejournal.warmadewa.ac.id/index.php/wmbj

Widarni, E. L., \& Irawan, C. B. (2020). Analisis motivasi pelayanan publik dan role stress terahdap kinerja pegawai dengan komitmen organisasi sebagai variabel intervening pada PT Kereta Api Indonesia DAOP VIII. Dinamika Governance : Jurnal Ilmu Administrasi Negara, 10(2), 120-134. 